\title{
STANLEY FISH
}

\section{Notatki z Folger}

$\mathrm{O}$ problemach poruszanych $\mathrm{w}$ niniejszej książce ${ }^{\mathrm{T}}$ rozmyślałem już wcześniej, prowadząc (30 listopada i 1 grudnia 1990 roku) warsztaty w bibliotece Folger w Waszyngtonie. Przygotowując się do tamtego seminarium, napisałem kilka ponumerowanych fragmentów dotyczących kluczowych problemów i poprosiłem uczestników, by się do nich odnieśli. Jak łatwo się przekonać Profesjonalna popraweność to rozwinięcie Notatek z Folger.

\section{Argument za intencją}

1. Nie da się zrozumieć znaczenia bez ustalenia intencji, bez przyjęcia, że to, co rozumiemy, wynika z naszej świadomości celu.

2. Z tego względu próba zrozumienia, co jakaś rzecz znaczy, zawsze wymaga określenia intencji.

3. Nie można więc odróżnić interpretacji intencjonalnej od innych rodzajów interpretacji. Wszystkie interpretacje są interpretacjami intencjonalnymi, choć stwierdzenie to nie mówi nam niczego o naturze wykładników intencjonalności [intending agent - dowodach, na które można się powołać, procedurach, które można zastosować. Intencjonalizm to nie metoda interpretacji, lecz fakt dotyczący każdej interpretacji, fakt na tyle ogólny, że pozostawia wszystkie empiryczne pytania interpretacyjne (jedyne, jakie możemy zadawać) otwarte.

4. Istnieje oczywiście możliwość, by szukać w tekście czy zestawie tekstów jakichś regularności niezależnie od intencji, ale to jedynie wskazuje, że poza interpretowaniem tekstów można $\mathrm{z}$ nimi robić wiele innych rzeczy.

I Thumaczenie na podstawie: S. Fish, Professional Correctness. Literary Studies and Political Change, Oxford 1995. 
5. Intencjonalizm nie stanowi kwestii spornej, nie jest zagadnieniem interesującym dla teoretyka, jedyne ważne pytanie brzmi bowiem, w jakich miejscach należy szukać jego śladów, ale to zagadnienie nie jest już problemem teoretycznym.

6. Punkty 1-5 w żaden sposób nie przywracają pojęcia autorskiej władzy sprawowanej przez spójne ja, które rozumie swoje projekty w bezproblematyczny sposób. Każde określenie intencji można zakwestionować i zastąpić, ale tym, czym można je zastąpić, będą zawsze inne określenia intencji i dotyczy to także sytuacji, kiedy intencja, którą odczytujemy (lub ododczytujemy), jest naszą intencją.

\section{Argument przeciwko historycyzmowi (nie przeciw historii, bo to nie miałoby sensu)}

1. Wszystkie działania, zarówno fizyczne, jak i językowe, podejmowane, są w odniesieniu do historycznych okoliczności i to te okoliczności, a nie jakieś transcendentalne struktury, określają ich znaczenie.

2. Skoro wszystkie działania są umocowane historycznie, nie sposób stworzyć hierarchii działań (metod, procedur) różniących się od siebie stopniem historyczności. Ponieważ wszystko jest historyczne, nie można wybrać jakiejś metody czy punktu widzenia, argumentując, że są one bardziej historyczne od innych, konkurencyjnych metod i punktów widzenia. Historyczność to nie wybór, ale coś nieuniknionego i z tego względu nie może stać się ona podstawą do rozróżniania między metodami interpretacyjnymi.

3. To, co jest przeciwstawiane w dyskusjach dotyczących metody, to różne wersje historycyzmu. Nie można przeciwstawiać historycyzmu czemuś innemu, gdyż nie ma niczego innego.

4. Dyskusje dotyczące metody mogą być rozstrzygane w odniesieniu do wielu różnych kryteriów (wszystkie z nich są interpretacyjne), ale jedynym kryterium, którego nie można zastosować, jest kryterium: „bardziej historyczne” kontra „mniej historyczne".

5. Historycyzm to nie metoda i dlatego określanie się mianem historycysty niczego nie oznacza, niczego nie daje, nie czyni nas bardziej historycznymi, niż byliśmy wcześniej (co to w ogóle miałoby znaczyć?). Ci z kolei, którzy określają siebie jako antyhistorycznych (kolejne określenie, które nic nie znaczy), niczego nie tracą, czyniąc ów teoretyczny błąd, gdyż są tak samo osadzeni w historii jak wszyscy inni. 
6. Wynika stąd, że nie istnieją metodologiczne konsekwencje bycia świadomym naszego osadzenia w historii. Świadomość ta mogłaby owocować różnicą metodologiczną tylko wtedy, gdyby pozwalała nam uwolnić się czy zdystansować od historyczności, którą głosi. Ale to oznaczałoby, że historycystyczny punkt widzenia jest $\mathrm{w}$ istocie metodą ucieczki od historii, przepustką pozwalającą wydostać się z lokalnych warunków, w których żyjemy, poruszamy się i tkwimy. Gadamer twierdził, że „prawdziwe myślenie historyczne musi brać pod uwagę własną historyczność", ale to jest właśnie to, czego prawdziwe historyczne myślenie (myślenie, w które nieuchronnie jesteśmy uwikłani) nie może uczynić bez zaprzeczenia własnej historyczności, bez przedstawiania siebie jako uprzywilejowanego punktu obserwacyjnego, z którego oddziaływanie aktualnego momentu historycznego może być dostrzeżona, może jej zostać postawiony opór i w pewnym sensie może zostać przekroczona [transcended]. W swojej mocnej odmianie, która pretenduje do posiadania historycznej świadomości na poziomie nieosiągalnym dla innych i politycznej wyższości wynikającej z niezwykłej samoświadomości, nowy historycyzm jest nową transcendencją.

7. Punkty 1-6 odnoszą się równie dobrze i na tej samej zasadzie do argumentów dotyczących krytyki politycznej i interdyscyplinarności.

\section{Argument przeciwko krytyce politycznej (nie przeciw polityce, to byłoby bez sensu)}

1. Pojęcie „krytyka polityczna” jest rozumiane zazwyczaj na dwa sposoby: albo jako coś przeciwstawnego krytyce, która trzyma się z dala od świata społecznego i politycznego - „ponadczasowej" krytyce, albo jako odmiana krytyki, której intencją jest wywoływać zmiany w świecie poza granicami nakreślonymi ramami dyscypliny czy instytucji. Wielu z nawołujących do uprawiania krytyki politycznej (lub tych, którym wydaje się, że już ją uprawiają) myśli, że równocześnie robi dwie rzeczy naraz: że przeciwstawia się ponadczasowej krytyce i zmienia świat i wierzy, że, robiąc to pierwsze, zaczyna automatycznie robić to drugie.

2. Jednakże problem $\mathrm{z}$ definiowaniem siebie jako przeciwnika krytyki ponadczasowej polega na tym, że zgodnie z podstawowym założeniem krytyki politycznej - założeniem, że wszystkie działania są polityczne, wyobrażalne i możliwe do podjęcia tylko z jakichś partykularnych punktów widzenia - nie może 
istnieć coś takiego jak krytyka ponadczasowa. Gdyby istniało coś takiego - krytyka będąca w kontakcie z ogólnymi prawdami dotyczącymi tego, co kryje się pod widzialną warstwą rzeczywistości - wszyscy byśmy się nią zajmowali, bo zajmując się nią, wiązalibyśmy swój głos z głosem Boga.

To, co zazwyczaj określamy mianem krytyki ponadczasowej, to krytyka tworzona w odniesieniu do estetycznych, teologicznych lub psychologicznych słowników. Są one oczywiście w takim samym stopniu historyczne i polityczne jak wszystkie inne (gdyż pojawiają się w określonych momentach historycznych, pod presją określonych wyobrażeń), lecz ich historyczna i polityczna tożsamość jest ściśle związana z roszczeniem do niebycia ani historycznymi, ani politycznymi. To roszczenie nie jest jednak możliwe do spełnienia i gdy ktoś sprzeciwia się pracy wykonywanej pod jego egidą, sprzeciwia się nie ponadczasowości, lecz jakiejś wersji czasowości i robi to z pomocą (i w służbie) swojej wersji czasowości. Mówiąc inaczej, starcie zachodzi zawsze między dwoma rodzajami krytyki politycznej: jedną twierdzącą (nieprawdziwie), że nie jest polityczna, i drugą twierdzącą (nieprawdziwie), że tylko ona jest polityczna. Nie jest też tak, jak się czasem mówi, że ci, którzy praktykują „ponadczasową” krytykę, są powiązani z siłami dążącymi do podtrzymania status quo, gdyż - jak zauważył Dollimore - „kluczowym problemem jest zrozumienie, w jaki sposób esencjalistyczne teorie podmiotowości zostały wykorzystane, by wesprzeć radykalne działania" ${ }^{2}$. I na odwrót - silnie antyesencjalistyczne teorie (mówiące o niedostępności transkontekstualnego punktu odniesienia) były z kolei wykorzystywane przez konserwatystów.

3. Ostatecznie więc nie istnieje coś takiego jak krytyka polityczna - jeśli rozumiemy przez to pojęcie krytykę, która jest w większym stopniu (a nie w inny sposób) uwikłana w społeczne, ekonomiczne czy polityczne zjawiska niż inne rodzaje krytyki. Pomimo to termin „krytyka polityczna” odgrywa funkcjonalną rolę, gdy stosuje się go do oznaczenia pewnego rodzaju literaturoznawczej aktywności, w której materiał analizy jest raczej polityczny niż estetyczny, teologiczny czy psychologiczny. To oczywiście starsze rozumienie krytyki politycznej. Istnieje nowsze znaczenie: krytyka polityczna obejmuje w tym wypadku odkrywanie praktyk dyskursywnych, konstytutywnych zarówno dla literatury, jak i dla kultury, której jest ona rozwinięciem. $\mathrm{W}$ tej odmianie badań granica między tym, co literackie, i tym, co nieliterackie, zostaje zamazana i przekroczona (a w niektórych przypadkach uznana za nieistniejącą), nacisk zaś kładzie się już nie na cechy (rytmu, stylu, dykcji, punktu widzenia, gło-

2 J. Dollimore, Radical Tragedy, New York 1989, s. IX-XII. 
su itd.) uznawane za „estetyczne”, ale na kulturowych wzorcach obecnych we wszystkich aspektach życia społecznego i politycznego. Myśląc o tych nowych metodach pracy, można zadać przynajmniej dwa pytania: 1) czy ta nowa metoda pracy to badania literackie czy coś innego (np. badania kulturowe)?, 2) jeśli są to badania kulturowe (jak wielu by chciało), czy są one polityczne $\mathrm{w}$ wąskim sensie aktywnego interweniowania w aktualny polityczny porządek? Na pytania te często odpowiada się z pomocą założenia, że przejście od badań literackich (rozumianych jako działalność typowo specjalistyczna) do badań kulturowych to przejście od czegoś małego i sztucznie wyizolowanego do czegoś większego i więcej obejmującego. Ja sugerowałbym jednak, że przejście to jest przejściem od jednego dyscyplinarnego namysłu do innego, żaden z nich nie jest ani bardziej, ani mniej sztuczny, ani bardziej, ani mniej wewnętrzny względem granic akademii. Te dwa rodzaje pracy oczywiście różnią się od siebie, ale różnice między nimi wynikają z faktu, że są to dwie odmienne formy pracy akademickiej, nie zaś z faktu, iż jedna z nich jest pracą akademicką, druga zaś pracą, która wywiera bezpośredni wpływ na pozaakademicki świat.

4. Aby praca wpływała bezpośrednio na świat pozaakademicki, musi być wykonywana dla jakichś pozaakademickich celów, np. by redystrybuować przychód, zwiększyć nakłady na świadczenia społeczne, zmienić politykę zagraniczną. Praca wykonana ze względu na te powody nie będzie postrzegana jako akademicka, gdyż dowody, które przedstawiła, publiczność, której dowody te zostały przedstawione, kształt argumentów, które były treścią tej prezentacji, i tradycja, wewnątrz której dowody i argumenty zostały stworzone, będą należeć do innego kontekstu, innego dyskursywnego (i materialnego) świata. W świecie akademickim praca jest, ogólnie biorąc, interpretacyjna, jest kwestią pytania tekstu, kulturowej regularności lub historycznego zdarzenia: „co to znaczy?”, „o czym to jest?”, „na co to wskazuje?” lub „co to zapowiada?”, pytań, które się od siebie istotnie różnią, ale które łączy wspólny cel - odkrycie prawdy na jakiś temat. Taka praca jest polityczna w tym sensie, że jakąkolwiek formę przyjmie, będzie zawsze zajmować partykularną (tj. sporną i spierającą się z innymi) pozycję wewnątrz dyskursywnego pola danej dyscypliny i jej historii, ale nie będzie polityczna w sensie bycia odpowiedzią na palące kwestie związane z polityką zagraniczną, dobrobytem społecznym i kryzysami ekonomicznymi. Oczywiście praca akademicka, nawet praca interpretacji literackiej, może być zawsze zastosowana do „realnego świata” polityki, lecz jeśli tak się stanie, przestanie być odpowiedzialna względem wymagań akademickich i dezy- 
deratów, będzie raczej zatrudniona i oceniana w odniesieniu do wymagań i dezyderatów jakiegoś jawnie politycznego celu. Jeśli, na przykład, ktoś chciałby wykorzystać Raj utracony, dążąc do jakichś celów politycznych, nie pytałby: „co to znaczy?”, ale: „jak mogę wykorzystać jedną lub wiele odpowiedzi na pytanie: «co to znaczy?», by poprzeć taką lub inną sprawę?" - i jego zobowiązanie dotyczyłoby nie prawdziwości interpretacji, lecz jej efektywności w osiągnięciu zamierzonego celu. Nie chodzi o to, że praca interpretacyjna nie ma $\mathrm{w}$ sobie celowego lub perlokucyjnego elementu (bo wykonując ją, zawsze staramy się przekonać kogoś, że mamy rację), ale o to, że w kontekście tego celu nie musimy uważać na polityczne zamieszanie, które wywoła nasza interpretacja. (To oczywiście nie stosuje się do dyscyplin, które w przeciwieństwie do badań literackich i kulturowych znajdują się $\mathrm{w}$ bezpośrednim kontakcie $\mathrm{z}$ rządowymi, a nawet globalnymi zadaniami; ekonomiści na przykład oczekują, że to, co robią, równocześnie wpłynie na politykę monetarną i przyniesie odpowiedzi na podstawowe pytania w ich dyscyplinie, o czym będę jeszcze pisał). Istnieje więc ogromna różnica między próbą odkrycia, jakie jest znaczenie danego wiersza, a próbą odkrycia, która z jego interpretacji przyczyni się do podważenia patriarchatu czy obalenia kapitalizmu. Pierwszy wysiłek jest inteligibilny w związku z definicjami, wymaganiami i założonymi celami danej dyscypliny i w odniesieniu do nich zostanie oceniony, drugi rodzaj dążenia pomija lub traktuje z pragmatyczną obojętnością te same definicje, wymagania i cele, gdyż pragnie osiągnąć coś zupełnie innego. Biorąc pod uwagę aktualny związek między sytuacją $\mathrm{w}$ badaniach literackich a problemami polityki narodowej (z możliwym wyłączeniem polityki edukacyjnej), trzeba zauważyć, że jest nieprawdopodobne, by ów drugi rodzaj dążenia osiągnął zamierzony cel. Jeśli chcielibyśmy działać politycznie w „prawdziwym świecie”, to istnieją (a przynajmniej istnieć powinny) lepsze narzędzia w naszym warsztacie niż czytanie wierszy, tekstów kultury czy nawet samych kultur.

5. Tutaj pojawia się możliwość wyboru. Można wybrać pracę interpretacyjną, próbować odkryć prawdę o tekstach, wydarzeniach czy kulturach (jednakże, jak zauważa Walter Michaels, nie możemy wybierać swoich interpretacji) lub można wybrać pracę polityczną, nie można jednak podjąć się pracy interpretacyjnej (przynajmniej nie w naukach humanistycznych) $\mathrm{z}$ intencją wykonywania pracy politycznej, gdyż, jeśli tylko zdecydujemy się na działania polityczne - to znaczy, gdy wyznaczymy sobie konkretny polityczny cel - będziemy zależni i odpowiedzialni względem kryteriów, które nie respektują ani nawet nie rozpoznają kryteriów akademickich. Robiąc tak - angażując się 
w problematyczne z punktu widzenia akademii praktyki - nie będziemy nieuczciwi, ale będziemy uczciwi w inny sposób, gdyż nie będziemy się angażować $\mathrm{w}$ ogóle w praktyki akademickie i ta różnica - proceduralna, konceptualna, związana ze sposobem oceny pracy - czyni prawdziwą różnicę.

6. Nie oznacza to jednak, że praca interpretacyjna nie ma implikacji politycznych czy konsekwencji. Byłoby to niemożliwe, gdyż, jak dowodziło wielu, żadna aktywność nie umożliwia i nie autoryzuje siebie samej, określone miejsce i inteligibilność zostają jej dane w związku z założeniami, priorytetami i strukturami władzy, które już istnieją w społeczeństwie. Dlatego, jak wskazuje Montrose, praca intelektualna jest nie tylko „społecznie produkowana”, ale także "społecznie produktywna”, oddziałuje z powrotem na dyskursywną/polityczną strukturę, która ją wytworzyła. Mimo to nie można twierdzić, tak jak robi to Montrose, że „polityka akademii wykracza poza to, co normalnie rozumiemy przez pojęcie «akademickiej polityki»" 4 , to znaczy, nie możemy tak twierdzić, jeśli Montrose chce nam tym samym powiedzieć, że przez angażowanie się w politykę akademii - oferowanie jakiejś interpretacji zamiast innej (żadna $\mathrm{z}$ nich nie została wybrana) - interweniujemy bezpośrednio lub choćby $w$ jakiś przewidywany przez nas sposób w politykę dotyczącą naszego społeczeństwa. Ponieważ żadne działanie podjęte w jakiejkolwiek dziedzinie nie pozostaje bez konsekwencji dotykających świat współzależnych praktyk, wszystkie interpretacyjne wysiłki w jakiś rozcieńczony, odroczony sposób wpływają na historię świata, lecz konsekwencje takie, mimo iż są realne, nie są tym, co działający w obrębie akademii aktor lub aktorka ma na myśli, kiedy gra w swoją grę, gdyż jego lub jej umysł będzie $\mathrm{w}$ momencie działania wypełniony kryteriami i dezyderatami specyficznymi dla tej sytuacji. Montrose może chcieć wierzyć, że „wybierając [słowo najgorsze z możliwych - S.W.] jako pierwszoplanowe w swojej lekturze Szekspira czy Spensera kwestie takie, jak polityka dotycząca płci kulturowej, sprzeciw wobec ograniczania społecznych swobód”, nie tylko „angażuje się $\mathrm{w}$ bezustanne odkrywanie na nowo [re-invention] elżbietańskiej kultury, ale [...] także stara się, by to zaangażowanie pomogło w przemianie nas samych" ${ }_{5}$, jednak jeśli nie myśli o tym staraniu jako o niepewnym i nieprzewidywalnym efekcie ubocznym (a nie jako dodatkowym produkcie jego pracy), jest skazany na zawód. Dzieje się tak nie dlatego, że nie mogłyby istnieć bardziej bezpo-

3 L.A. Montrose, Professing the Renaissance, w: The New Hitoricism, red. H. Aram Veeser, New York 1989, s. 23.

4 Ibidem, s. 30.

5 Ibidem. 
średnie powiązania między badaniami kulturowymi i wydarzeniami na szeroką skalę (dowodem przypadek Salmana Rushdiego czy Vaclava Havla), lecz dlatego, że ze względu na dystans istniejący między badaniami kulturowymi a strukturami władzy (chyba że jest się Ministrem Edukacji, rektorem Harvardu lub stoi na czele National Endowmnent for the Humanities) takie działania osiągną swe polityczne cele w wyjątkowo nikłym stopniu.

Oczywiście, jeśli ktoś chce pokładać nadzieję w niepodważalnym fakcie, że edukacja młodych w końcu zaowocuje rozwojem społeczeństwa, i argumentować, że wprowadzenie pojęcia płci kulturowej oraz innych punktów widzenia wpłynie na ten rozwój, nie będę protestował (i pewnie nikt nie będzie), tak długo, jak długo pamiętamy, że takie konsekwencje nie są tym, o co nam chodzi, gdy wykonujemy intelektualną pracę (bo gdyby o to chodziło, nie byłaby to już praca intelektualna), i że sposób, w jaki wprowadzenie pojęcia płci kulturowej oraz innych perspektyw zaowocuje w życiu oraz karierze naszych studentów, jest całkowicie przypadkowy.

7. Podsumowując: argument za krytyką polityczną jest (a) albo zbyteczny, gdyż każda krytyka jest polityczna w słabym i nieróżnicującym sensie, (b) albo jest wezwaniem, by wybrać pewien rodzaj akademickiej pracy zamiast innego, (c) albo jest wezwaniem, by uprawiać badania niezakorzenione w tradycjach i dezyderatach związanych ze specyficznym umiejscowieniem (na uniwersytecie czy wewnątrz jakiejś dyscypliny), badania, których zainteresowania i efekty są raczej ogólne niż lokalne. Jeśli jest tak, jak w trzecim przypadku, wydaje się dość ironiczne, że wojujący historycyzm domaga się działań mających nas wydostać lub transcendować ze specyficznej historycznej sytuacji umożliwiającej ich zaistnienie, że domaga się działań, które są ponadczasowe.

\section{Argument przeciw interdyscyplinarności (nie przeciwko pracy interdyscyplinarnej, bo to nie miałoby sensu)}

1. Żądanie krytyki politycznej jest powiązane, a może nawet współwystępuje, $\mathrm{z}$ atakiem na dyscypliny, wydziały i zawody jako hegemoniczne narzucenia [impositions] specyficznych i partykularnych perspektyw, ograniczające to, co powinno być polem autentycznej - to jest interdyscyplinarnej - wiedzy. Rozumowanie jest proste: dopóki czyjeś wysiłki są „zaledwie” dyscyplinarne - odpowiedzialne względem takiej czy innej tradycji badań akademickich - nie mogą wpływać na świat poli- 
tyki, dlatego powinniśmy odmówić pozostawania ograniczonym przez działanie wewnątrz założeń i celów określonej dyscypliny oraz „przebić się na zewnątrz”. To, do czego mamy się przebić w niektórych wersjach tego rozumowania, to ogólna mądrość, istniejąca poza granicami dyscyplin, mądrość, która może zostać nabyta przez ogół społeczeństwa, jeśli tylko nie będzie mu dostarczana $\mathrm{w}$ formie akademickiego żargonu. Jak pisze Ben $\mathrm{Ag}-$ ger: „Dyskurs musi ucieleśniać ogólną zrozumiałość, to znaczy [...] unikać ograniczonej podrzędności względem dyscyplin, $\mathrm{z}$ ich mocno zróżnicowanymi żargonami" ${ }^{6}$. Problem z dyscyplinami, jak twierdzi ten sam autor, polega na tym, że „praca musi przejść przez tyle redakcyjnych i wydawniczych systemów selekcyjnych, że nieuchronnie nabiera pewnej homogeniczności [...]. W akademickiej twórczości prawdziwym autorem jest dyscyplina" 7 . Te dwa stwierdzenia są ze sobą sprzeczne: $z$ jednej strony dyscypliny tak się różnicują, że odcinają się od ogólnej perspektywy, z drugiej strony działają z taką ograniczającą swobodę siłą, że tłamszą różnicę. Ten rozdźwięk jest oczywisty, ale pomocny, gdyż pozwala nam skupić się na kluczowej kwestii $\mathrm{w}$ badaniach interdyscyplinarnych: na kwestii różnicy. To $\mathrm{w}$ imię różnicy - rozpoznania perspektyw, materiałów i interesów wykluczonych z zainteresowania poszczególnych dyscyplin - żąda się interdyscyplinarnej pracy, pracy, która zmusza, by patrzeć na podwórko naszych sąsiadów. Jeśli jednak wezwanie do interdyscyplinarności przybiera polityczny - zazwyczaj utopijny - odcień, różnica ma zostać przekroczona w tej doniosłej chwili, gdy wszystkie partykularne i skrzywiające poglądy zostaną wymienione na szersze, bardziej ogarniające spojrzenie ogólnej mądrości. Jak tłumaczy to Julie Klein, za impulsem interdyscyplinarności kryje się „idea zjednoczonej nauki, ogólnej mądrości, syntezy, integracji wiedzy" ${ }^{8}$.

2. Na dużo mniejszą skalę koncepcje zsyntetyzowanej i ogólnej wiedzy były istotne dla ideału interdyscyplinarności, jaki pojawia się w badaniach literackich. Wczesnym, choć wymownym przykładem jest stwierdzenie Cleantha Brooksa w jego ostatniej polemice z Douglasem Bushem: „historyk literatury i krytyk winni pracować razem i [...] idealnym przypadkiem jest, gdy obie funkcje łączy ta sama osoba" ${ }^{9}$. W zdaniu tym wyśledzić można dwa oblicza interdyscyplinarnej transcendencji. Jeśli skierujemy zwielokrotnione reflektory różnych dyscyplin na obiekt poetyc-

${ }^{6}$ B. Agger, The Decline of Discourse, New York 1990, s. 37.

7 Ibidem, s. 145.

8 J. Klein, Interdisciplinarity, Detroit 1989, s. 19.

9 C. Brooks, Marvell's „Horatian Ode”, w: Seventeenth Century Poetry, red. W.R. Keast, London 1962, s. 355. 
ki - sam w sobie bardziej skomplikowany i obszerny w swej istocie niż jakikolwiek słownik czy system opisu - zostanie on ujrzany w prawdziwy, to jest aperspektywiczny i niepartykularny sposób, a jeśli te same zwielokrotnione reflektory zostaną włączone wewnątrz pojedynczego umysłu, umysł ten, a więc osoba nim zawiadująca będzie równie aperspektywiczna, nieograniczona do jednego punktu widzenia czy metodologii. „Idealna sytuacja”, o której mówi Brooks, jest podwójnie idealistyczna: oznacza wyłonienie się idealnego (pełnego, zsyntetyzowanego) przedmiotu i idealnej (pełnej, zsyntetyzowanej) osoby.

3. Kontrargument jest bardzo prosty i polega na postrzeganiu różnicy jako czegoś raczej poważnego niż godnego pożałowania oraz tymczasowego. Wygląda on tak: przedmioty (także teksty) nie mają tożsamości poza dyskursywnymi praktykami, a osoby nie mają integralnej istoty, która wyłoni się, jeśli tylko wydostaniemy się poza ograniczenia narzucane przez dyscypliny. Przedmioty (także teksty) jawią się nam wewnątrz słowników związanych z określonymi przedsięwzięciami (prawem, literaturą, ekonomią, historią itd.) i w związku z celami, których te przedsięwzięcia są sposobami realizacji [instatnitation]. Zastosowanie słowników związanych $\mathrm{z}$ różnymi przedsięwzięciami do opisu jakiegoś przedmiotu nie pozwoli nam dostrzec różnych aspektów „złożoności” tego przedmiotu czy jego niewysłowionej istoty, lecz raczej ukonstytuuje różne przedmioty. Zaczynamy z ideą celu wywiedzioną z jakiegoś przedsięwzięcia, jakiegoś rozpoznawalnego projektu i z pomocą tej idei czynimy użytek $\mathrm{z}$ materiału, który akurat mamy pod ręką, łącznie z materiałami stworzonymi przez inne przedsięwzięcia, ale materiały te będą przejmowane (i postrzegane) w kształcie odpowiednim do pracy i zadań, które aktualnie wykonujemy. Ci, którzy narzekają - a dzieje się to ostatnio często - że materiały z ich dyscyplin zostały „wykrzywione”, „strywializowane” czy „przemienione w metafory" przez ludzi zajmujących się inną dyscypliną, równocześnie mają rację i mylą się. Z perspektywy, którą zajmują, relewancja materiału została zlekceważona, ale ci, którzy szukają pomocy, rozglądając się wkoło, postrzegają relewancję tych materiałów w odniesieniu do zupełnie innego zestawu celów i dlatego nie widzą ich w ogóle. Kiedy Paul de Man i inni pożyczyli rozróżnienie performatywne/konstatywne z teorii aktów mowy, wykorzystali je, pomijając podstawowe założenia tej teorii. Ponieważ nie działali na polu aktów mowy, ale na obszarze, na którym słownictwo związane $\mathrm{z}$ aktami mowy okazało się pomocne, nie można ich za to winić. Tak naprawdę winni byliby tylko wtedy, gdyby wszystkie słowniki uczestniczyły w jednym (i przez to były odpowiedzialne względem jednego) uniwersal- 
nym zadaniu, lecz słowniki są specyficzne dla i konstytutywne względem partykularnych zadań oraz zdobywają jakąkolwiek siłę lub przydatność w związku z określonymi celami. Historyk-krytyk, połączenie, które wyobraża sobie Brooks, nie będzie jedną, lecz dwoma osobami lub jedną (fizycznie zdefiniowaną) osobą, która wykonuje na przemian różne zadania i kiedy wykonuje jedno lub drugie $\mathrm{z}$ nich, jest inną osobą. Jako jedna $\mathrm{z}$ tych osób zauważyłby oczywistość $X$ i urok $Y$, jako ta druga nigdy nie zobaczyłby $X$ i $Y$ lub gdyby je zobaczył, nie miałyby one związku $\mathrm{z}$ jego aktualnym działaniem.

Ideały zunifikowanych zadań, zunifikowanego przedmiotu, korpusu zunifikowanej wiedzy i zunifikowanego ja upadaja wobec faktu istnienia nieredukowalnej różnicy. Jeśli jesteśmy (jak wszyscy dziś twierdzą) zawsze usytuowani, to nasza świadomość alternatywnych przebiegów działan i świadomość nas samych jako aktorów są specyficzne dla konkretnej sytuacji i nigdy nie mogą zostać rozszerzone, choć mimo to często będą się różnić.

4. Wszystko to niedawno dobitnie wyraził Patrick Hogan:

powinniśmy rozpocząć od przypomnienia, że zobowiązania są $\mathrm{w}$ znacznym stopniu związane $\mathrm{z}$ funkcjami lub opisami. $\mathrm{Z}$ tego względu jako ktoś, kto prowadzi zajęcia dotyczące Króla Leara to znaczy, dopóki działam opisany jako ktoś „prowadzący zajęcia o Królu Learze" - jestem zobligowany tak prowadzić zajęcia, by Król Lear stał się zrozumiały dla moich studentów, spotykać się ze studentami poza zajęciami, by pomóc im zrozumieć Króla Leara itd. Moje obowiązki jako człowieka w ogólności nie obligują mnie do wyjaśniania Króla Leara. Takie zobowiązania mam tylko jako wykładowca $^{\text {Io }}$.

Poszedłbym dalej: nie ma czegoś takiego jak „obowiązki jako człowieka w ogólności”, są takie obowiązki, które wydają się oczywiste ze względu na i wymuszone przez jakąś partykularną funkcję czy rolę. Dotyczy to także roli tak zwanych ogólnych czy publicznych intelektualistów, których rzekome zniknięcie opłakiwała zarówno lewica, jak i prawica (Agger, Jacoby, Bloom, Bruce Robbins, Page Smithe, John Silber, Robert Alter, Frank Kermode itp.). Publiczny intelektualista to po prostu ktoś usytuowany nie na uniwersytecie, ale w jakiejś innej, instytucjonalnej przestrzeni: w osiemnastowiecznej Anglii były to kawiarnie, w latach sześćdziesiątych XX wieku - Berkeley, Broadway i 116 Ulica, a w latach trzydziestych, czterdziestych i pięćdziesiątych XX wieku, gdy nasza literaturoznawcza republika była

то P. Hogan, The Politics of Interpretation, New York 1990, s. 184. 
jeszcze młoda - Cambridge i Concord (w stanie Massachusetts). Pojawiający się na jakimkolwiek forum publiczny intelektualista lub publiczna intelektualistka ma zadanie tak samo specyficzne, jak zadania specjalistów od średniowiecznej metryki, a jego czy jej publiczność jest nie mniej wyspecjalizowana, nawet jeśli jest (przynajmniej potencjalnie) większa. Pojęcie publicznego intelektualisty to opis stanowiska [job description], a nie honorowy tytuł przyznawany tym, którzy uciekli z granic wyznaczanych przez wszystkie inne zawody, i jest to opis stanowiska mającego specyficzne wymagania oraz określanego przez odmienne (lecz zawsze konkretne i ograniczone) praktyki w różnych czasach. W dzisiejszych czasach wydaje się to opis stanowiska gospodarzy talk shore, co ma swoje dobre i złe strony, zależnie od tego, czy ktoś lubi Phila Donahue'a, Teda Koppela, Dicka Cavetta, Pata Butchanana, Williama Buckleya, Billa Moyersa lub (dawno, dawno temu) Johna Searle'a. Mówiąc w skrócie, publiczny intelektualista to kolejny profesjonalista praktykujący kolejną dyscyplinę i ustanawiający wizję nie mniej, nie bardziej rozległą niż wizja jakiegokolwiek innego profesjonalisty zajmującego się jakąkolwiek inną dyscypliną. Dobra nowina interdyscyplinarności zależy od możliwości podejmowania działań, które są zrozumiałe nie tylko w lokalnym kontekście i z tego względu mają ponadlokalne konsekwencje. Nie ma takich działań, chociaż w pewnych warunkach politycznych działania podejmowane $\mathrm{z}$ jakichś lokalnych perspektyw mogą być nadrzędne. Nie byłoby to jednak tryumfem interdyscyplinarności, lecz zwycięstwem jednej $\mathrm{z}$ dyscyplin lub partykularnego projektu nad pozostałymi.

5. Dyscypliny są konserwatywne, co oznacza, że określony cel, będący ich rdzeniem, podtrzymywany jest zazwyczaj przez wchłanianie i czynienie własnymi zadań, których dostarczają historia i przypadek. Nie powinno więc nikogo dziwić, że energia powstająca $\mathrm{w}$ wyniku likwidowania dyscyplin i przemieniania (przez likwidowanie dyscyplin) akademickiej pracy $\mathrm{w}$ pracę prawdziwie polityczną (to znaczy prawdziwie interdyscyplinarną) jest bezustannie absorbowana i udomowiana przez przedmiot tych zabiegów. Jak wyjaśnia Don Wayne, istnieje niebezpieczeństwo, że nacisk położony na „intertekstualne relacje [...] przyniesie takie skutki dla naszych badań, jakie wcześniej przyniosły kategorie generatywne, funkcje narracyjne i mechanizmy stylistyczne" "I - to znaczy, że jako specyficzne dla danej dyscypliny konstrukty sprawią, iż nasza praca stanie się jeszcze bardziej dyscyplinarna. Michael Bristol ponuro przepowiada, że

II D. Wayne, Power, Politics, and the Shakespearean Text, w: Shakespeare Reproduced. The Text in History and Ideology, red. J. Howard, M. O'Connor, New York 1987, s. 61. 
„krytyczne badania prawdopodobnie zaowocują legitymizacją, a nie praktycznie efektywną krytyką, ${ }^{\text {I2 }}$. Ma rację, jeśli przez „efektywną krytykę" rozumie krytykę świata poza akademią, a nie (znów słowa Wayne’a) ,jedynie zastąpienie istniejącej krytycznej ortodoksji” ${ }^{{ }_{3}}$ nową ortodoksją.

6. Ostatecznie pragnienie prawdziwie historycznych, politycznych czy interdyscyplinarnych badań jest czymś podobnym do pragnienia akademii, szczególnie jej części humanistycznej, by być czymś więcej, niż jest ona w rzeczywistości. Nie może być tak, że stworzenie nowego opisu Króla Leara dla naszych kolegów to wszystko, co możemy zrobić, musi być tak, że jeśli stworzymy właściwy opis - taki, który wystarczająco odpowiada ogólnym potrzebom społeczeństwa - społeczeństwo nas posłucha, a nasi rodzice wreszcie zrozumieją, czemu wybraliśmy taki, najwyraźniej donkiszotowy zawód. Trzydzieści lat temu mogliśmy przedstawiać siebie samym sobie i innym jako obrońców dziedzictwa kulturowego (niektórzy oczywiście nadal żarliwie pragną, byśmy znowu nimi byli) lub, jeśli nie jako nieuznawanych prawodawców świata, to przynajmniej jako niezbędne narzędzia tych prawodawców („uczyń mnie swoją lirą”). Te uzasadnienia zostały $\mathrm{w}$ dużym stopniu zdyskredytowane, $\mathrm{w}$ wyniku czego wielu zwróciło się ku nowym, odmiennym oczywiście od starych, lecz podobnych w żądaniu od naszej pracy efektów wykraczających poza salę wykładową, a nawet poza gwiazdy. Uzasadnienia jednakże nie są nigdy dostępne z zewnątrz. Jeśli ktoś zapyta, jak czyni to wielu $\mathrm{z}$ nas, co dobrego robimy $\mathrm{z}$ punktu widzenia tych, którzy chcieliby znaleźć lekarstwo na raka lub zaprowadzić pokój na Bliskim Wschodzie, odpowiedź może być tylko zniechęcająca. Lecz jeśli w odpowiedzi na żądania uzasadnienia opowiemy sobie i innym historię naszej dyscypliny i zanurzymy się, jak zanurzaliśmy się na studiach, w wiedzy i umiejętnościach specjalistycznego rzemiosła, możemy znaleźć satysfakcję w tej historii. A jeśli naprawdę nauczymy się, jak żyć z samymi sobą, a nie udawać, że jesteśmy tacy, jacy chcielibyśmy być, możemy nawet odnaleźć satysfakcję w tym, że odnaleźliśmy satysfakcję. Kiedy wszystko zostało już zrobione i powiedziane, nie ma powodu by jakakolwiek dyscyplina lub jakiekolwiek przedsięwzięcie istniały, $\mathrm{z}$ wyjątkiem takich, których istnienie daje światu jakieś zyski. Tym, co osiągamy, biorąc udział w jakimś przedsięwzięciu, jest szczególna, specyficzna przyjemność i pocieszenie, które ono zapewnia. Nie powinniśmy myśleć o tych przyjemnościach i po-

${ }_{2}$ M. Bristol, Lenten Butchery: Legitimation Crisis in „Coriolanus”, $\mathrm{w}$ : Shakespeare Reproduced, . The Text in History and Ideology, red. J. Howard, M. O'Connor, New York 1987, s. 220.

I3 D. Wayne, op.cit., s. 62. 
cieszeniach ani jako o narzędziach naszego zbawienia, ani jako o przeszkodach w tym zbawieniu, są tym, czym są, tak jak my jesteśmy tym, kim jesteśmy.

Przeł. Stanisław Wójtowicz

\section{STANLEY FISH}

\section{Notes from Folger}

The text written by Stanley Fish, which is an excerpt from his book Professional Correctness. Literary Studies and Political Change (Oxford 1995), is an attempt at a presentation and a discussion of the main conditioning factors and the aporia of interpretation. From among the four arguments given by the author, i.e. intention, historicalness, politicalness and interdisciplinarity, only the first one has been established to be an immanent feature of each of interpretations. This results from the conviction that while interpreting literary texts we are always subjected to the pressure of the surrounding premises. It is just the extensive and thorough analysis of these premises, to which the supporters of political, historical and interdisciplinary criticism refer to that makes the author of the sketch possible to show that behind each of the methods there are individual interests and a different vision of the world. To realize these determinants is to enable us to question the very need of universal interpretation. By questioning the theoretical fundamentals of the three mentioned modes of interpretation, the author admits frankly that the work of an interpreter can have both historical, political and just as well interdisciplinary character, though this observation is by all means tantamount to a recognition of the legitimacy of any of the criticized methods.

STANLEY FISH - amerykański teoretyk i krytyk literacki, jeden z najwybitniejszych przedstawicieli neopragmatyzmu oraz reader-response criticism, najważniejszy współczesny znawca twórczości Johna Miltona. Był wykładowcą wielu uczelni w Stanach Zjednoczonych, obecnie pracuje na Florida International University. Autor m.in. Is There a Text in This Class? Authority of Interpretative Communities (1980), Doing What Comes Naturally: Change, Rhetoric, and the Practice of Literary and Legal Studies (1989), The Trouble with Principle (1999), How Milton Works (2001). W Polsce ukazał się wybór esejów z dwóch pierwszych publikacji: Interpretacja, retoryka, polityka (2002).

STANISŁAW WójTOwiCz - doktorant w Zakładzie Poetyki i Krytyki Literackiej UAM. Autor Hip-bop stownika (wraz z Piotrem Flicińskim). Pisze rozprawę na temat Stanleya Fisha. 